\author{
Dhiana Puspitawati, Adi Kusumaningrum \\ Fakultas Hukum Universitas Brawijaya Malang \\ adi.kusumaningrumagmail.com
}

Naskah Masuk: 30 September 2015

Naskah Diterima: 3 November 2015

\title{
REPOSISI POLITIK HUKUM PERJANJIAN INTERNASIONAL DALAM RANGKA MEWUJUDKAN TERTIB HUKUM DI INDONESIA
}

\begin{abstract}
In Indonesia, here is no exact politic and legal system regarding the application of International Treaty within national legal system. Article 11 of Indonesian Constitution 1945 merely envisages the division of authority between President and Parliament in ratifying international treaty, however, such article does not state clearly Indonesia's legal politics concerning the application of international treaty within national legal system. The lack of clarification on Indonesia's legal and political system in such area raises problems in the application of international treaty domestically. This research is aimed to: (1) analyses Indonesia's legal politic concerning the application of international treaty towards Indonesian Constitution 1945 as well as other legal instruments; (2) analyses legal implications of international treaty upon Indonesia's national interests and; (3) propose concept on legal politic regarding the application of international treaty in Indonesia. Since legal politic is crucial in supporting which law should be implemented towards state's national goal, it is important to clarify Indonesia's legal politic concerning the implementation of international treaty. As stated by Hans Kelsen, that as the application of the rule of law, a state should eliminate existing inconsistency and overlaps of its laws.
\end{abstract}

Keywords: Reposition, Legal Politic, International Treaty, and Legal Order

\section{ABSTRAK}

Di Indonesia tidak ada politik dan hukum yang jelas terkait perjanjian internasional dalam sistem hukum nasional. Pasal 11 UUD 1945 hanya menerangkan tentang pembagian wewenang antara presiden dan parlemen dalam 
meratifikasi perjanjian internasional, namun, tidak ada pasal yang menjelaskan tentang penerapan perjanjian internasional dalam sistem hukum nasional. Tidak adanya klarifikasi mengenai sistem politik dan hukum di Indonesia dalam hal tersebut telah menimbulkan masalah dalam penerapan perjanjian internasional secara domestik. Penelitian ini bertujuan untuk: (1)Menganalisis hukum dan politik Indonesia terkait penerapan perjanjian internasional tentang UUD 1945 serta instrumen-instrumen hukum lainnya; (2) Menganalisis implikasi hukum dari perjanjian internasional terhadap kepentingan nasional Indonesia, dan; (3) Mengajukan konsep politik dan hukum mengenai perjanjian internasional di Indonesia. Karena hukum politik sangat penting dalam mendukung hukum yang perlu diimplementasikan dalam tujuan nasional suatu negara. hal ini sangat penting untuk mengklarifikasi hokum politik Indonesia mengenai implementasi perjanjian internasional. Seperti yang dikatakan oleh Hans Kelsen, layaknya supremasi hukum, negara seharunya menghilangkan inkonsistensi dan hukum tumpang tindih.

Kata kunci: Reposisi, politik hukum, perjanjian internasional, dan tatanan hukum

\section{PENDAHULUAN}

Pada tahun 2011, Undang-Undang Nomor 38 Tahun 2008 tentang Pengesahan Charter of the Association of Southeast Asian Nations (Piagam Perhimpunan Bangsa-Bangsa Asia Tenggara) dipermasalahkan oleh sejumlah Lembaga Swadaya Masyarakat (selanjutnya disebut LSM) dengan meminta Mahkamah Konstitusi melakukan judicial review (pengujian) terhadap undang-undang ratifikasi Piagam Asean ini terhadap Undang-Undang Dasar 1945 melalui perkara nomor 33/PUU-IX/2011. Gugatan judicial review oleh sejumlah LSM terhadap Undang-Undang Nomor 38 Tahun 2008 tentang Pengesahan Charter of the Association of Southeast Asian Nations didasarkan pada beberapa alasan, diantaranya adalah bahwa Undang-Undang Nomor 38 Tahun 2008 tentang Pengesahan Charter of the Association of Southeast Asian Nations sebagai landasan hukum perjanjian ekonomi antara ASEAN sebagai pasar tunggal dengan negara lain dan/atau komunitas negara-negara lain, telah melanggar ketentuan Pasal 33 ayat (1), ayat (2), dan ayat (3) dan Pasal 27 ayat (2) UUD 1945.

Terdapat beberapa hal khususnya dalam hukum perjanjian internasional yang menarik untuk dikaji lebih lanjut berkaitan dengan pengajuan judicial review undang-undang ratifikasi tersebut. Pertama, bagaimana posisi perjanjian internasional yang disahkan oleh undang-undang. Apakah norma-norma perjanjian internasional otomatis menjadi undang-undang atau harus dimuat lagi dalam undang-undang tersendiri. Apakah UU No. 38 Tahun 2008 tentang Pengesahan Charter of the Association of Southeast Asian Nations adalah identik dengan Piagam ASEAN sebagai traktat (perjanjian internasional), atau apakah materi normatif Piagam ASEAN telah menjelma menjadi UU No. 38 Tahun 2008 tentang Pengesahan Charter of the Association of Southeast Asian Nations. Hal ini tentu akan terkait dengan kewenangan MK untuk melakukan pengujian. Kedua, apakah mungkin dilakukan pembatalan sepihak oleh Indonesia terhadap Piagam ASEAN. Apakah pembatalan undang-undang ratifikasi perjanjian internasional tersebut akan berakibat kepada penarikan keikutsertaan Indonesia? Padahal sebelum dilakukannya ratifikasi melalui undangundang, Indonesia telah menyatakan keikutsertaannya melalui penandatanganan perjanjian internasional tersebut secara langsung atau melalui acceptance, approval, atau accession. Artinya ada pemberlakuan kedalam dan keluar. 


\section{0}

JURNAL MEDIA HUKUM

Pada tanggal 26 Pebruari 2013, Mahkamah Konstitusi mengeluarkan putusan perkara nomor 33/PUU-IX/2011 tentang pengujian undang-undang ratifikasi Piagam Asean ini terhadap UndangUndang Dasar 1945. Putusan Mahkamah Konstitusi ini memberikan jawaban apakah mekanisme konstitusi Indonesia memungkinkan suatu perjanjian internasional diajukan pengujian (judicial review) terhadap UUD 1945?

Dalam putusannya Mahkamah Konstitusi menyatakan bahwa berdasarkan Pasal 24C ayat (1) UUD 1945, Pasal 10 ayat (1) huruf a Undang-Undang Nomor 24 Tahun 2003 tentang Mahkamah Konstitusi sebagaimana telah diubah dengan Undang-Undang Nomor 8 Tahun 2011 tentang Perubahan Atas Undang-Undang Nomor 24 Tahun 2003 tentang Mahkamah Konstitusi (Lembaran Negara Republik Indonesia Tahun 2011 Nomor 70, Tambahan Lembaran Negara Republik Indonesia Nomor 5226, selanjutnya disebut UU MK), dan Pasal 29 ayat (1) huruf a Undang-Undang Nomor 48 Tahun 2009 tentang Kekuasaan Kehakiman (Lembaran Negara Republik Indonesia Tahun 2009 Nomor 157, Tambahan Lembaran Negara Republik Indonesia Nomor 5076, selanjutnya disebut UU 48/2009), salah satu kewenangan konstitusional Mahkamah adalah mengadili pada tingkat pertama dan terakhir yang putusannya bersifat final untuk menguji Undang-Undang terhadap Undang-Undang Dasar. Lebih lanjut Mahkamah Konstitusi menyatakan bahwa permohonan para Pemohon adalah pengujian konstitusionalitas norma Undang-Undang, yaitu Pasal 1 angka 5 dan Pasal 2 ayat (2) huruf n ASEAN Charter yang merupakan lampiran dan bagian yang tidak terpisahkan dari UU 38/2008 (vide Pasal 1 UU 38/2008), dengan demikian, Mahkamah berwenang untuk mengadili permohonan a quo. Mahkamah Konstitusi juga menyatakan bahwa meskipun Negara Indonesia telah mengikatkan diri dalam suatu perjanjian internasional, namun sebagai sebuah negara yang berdaulat Negara Indonesia tetap mempunyai hak secara mandiri untuk memutus keterikatan dengan perjanjian internasional yang telah dibuat atau yang padanya negara Indonesia terikat, setelah secara internal mempertimbangkan keuntungan atau kerugiannya baik untuk tetap terikat, ataupun untuk tidak terikat dengan mempertimbangkan risiko atas keputusan untuk keluar dari suatu perjanjian internasional. Mahkamah Konstitusi menyatakan bahwa hal ini dimungkinkan dengan ketentuan Pasal 18 huruf h Undang-Undang Nomor 24 Tahun 2000 tentang Perjanjian Internasional yang menyatakan, "Perjanjian internasional berakhir apabila:... h. terdapat hal-hal yang merugikan kepentingan nasional".

Konflik hubungan relasi antara hukum internasional dan hukum nasional tidak saja digambarkan oleh permohonan judicial review terhadap UU Nomor 38 Tahun 2008, akan tetapi juga permohonan pengujian materiil dan formil terhadap Undang - Undang Nomor 22 Tahun 2001 tentang Minyak dan Gas Bumi. Dalam kasus tersebut Kontrak Kerja Sama (KKS) minyak dan gas bumi, ditolak untuk dinyatakan sebagai perjanjian internasional, walaupun ditolak terlihat bahwa awalnya masyarakat yang menggugat UU No. 22 Tahun 2001 menganggap bahwa KKS adalah perjanjian internasional yang bertentangan dengan UUD 1945.(http://pustaka.unpad.ac.id/wpcontent/uploads/2015/03/Status-Perjanjian-Internasional-dalam-Sistem-Hukum-Indonesia.pdf.)

Ketidakjelasan posisi perjanjian internasional juga digambarkan pada permohonan pengujian 
materiil dan formil dilakukan terhadap Undang-Undang No. 1/PNPS/1965 tentang Pencegahan Penyalahgunaan dan Penodaan Agama. Yurisprudensi Mahkamah Agung dalam perkara pidana hak asasi manusia dengan terpidana Eurico Guterres, mantan Wakil Panglima Pasukan Pejuang Integrasi, menunjukan bahwa majelis hakim Mahkamah Agung merujuk langsung kepada perjanjian internasional tanpa tergantung kepada peraturan perundang-undangan nasional. Hal ini sesuai dengan aliran monisme. Namun demikian, Mahkamah Konstitusi dalam putusan tentang permohonan Pengujian Undang-Undang No. 1/PNPS/1965 tentang Pencegahan Penyalahgunaan dan Penodaan Agama, cenderung menganut dualisme. Hal tersebut karena hakim menyatakan Article 18 International Convenant on Civil and Political Rights telah diadopsi langsung oleh UndangUndang No. 39 Tahun 1999 tentang Hak Asasi Manusia. Dengan demikian hakim menganggap Undang-Undang No. 39 Tahun 1999 tentang Hak Asasi Manusia sebagai bentuk transformasi International Convenant on Civil and Political Rights (Latifulhayat dan Susi, 2011:190).

\section{HASIL DAN PEMBAHASAN}

\section{A. Politik Hukum Perjanjian Internasional Indonesia Dalam UUD 1945 dan Peraturan Nasional Indonesia}

Damos D. Agusman membagi rejim hukum bagi perjanjian internasional di Indonesia menjadi tiga rejim yang berbeda. Pertama periode tahun 1945-1960 dimana perjanjian internasional didasarkan pada 3 (tiga) UUD yang berlaku berturut-turut pada periode itu, yaitu UUD 1945, Konstitusi RIS 1945, dan UUDS 1950. Periode kedua adalah antara tahun 1960-2000, dimana sekalipun berlandaskan UUD 1945 perjanjian internasional tunduk pada ketentuan seperti yang diatur pada Surat Presiden 2826 tahun 1960. Periode terakhir adalah sejak tahun 2000 sampai saat ini yang ditandai dengan berlakunya UU Nomor 24 Tahun 2000 tentang Perjanjian Internasional.(Dewanto, 2009: 327.)

1. Politik Hukum Perjanjian Internasional Dalam Konstitusi Nasional Indonesia (Constitutional Legal Provisions)

Sejak awal konstitusi negara Indonesia tidak dirancang untuk mengantisipasi kasus-kasus hukum yang berkaitan dengan interaksi antara hukum nasional dengan hukum internasional, khususnya terkait dengan perjanjian internasional. Constitutional Provisions atau ketentuan Indonesia tentang masalah pilihan politik hukum masih minim dan belum mengindikasi apapun tentang politik hukum yang hendak dianut(Agusman, 2008: 490). Indonesia tidak mengatur secara tegas apakah hukum internasional berada dalam satu sistem dengan hukum nasional. Sebelum adanya perubahan UUD 1945, perjanjian internasional diatur dalam Pasal 11 UUD 1945 yang menetapkan bahwa: "Presiden dengan persetujuan Dewan Perwakilan Rakyat menyatakan Perang, membuat perdamaian dan perjanjian dengan negara lain". Pasal ini tidak secara khusus mengatur tentang perjanjian internasional, akan tetapi menempatkannya menjadi satu bagian dengan kekuasaan presiden lainnya dalam bidang hubungan luar negeri yaitu menyatakan perang dan membuat perdamaian. Aturan ini sangat singkat dan tidak dimaksudkan untuk mengatur tentang pembuatan perjanjian 


\section{2}

JURNAL MEDIA HUKUM

internasional itu sendiri melainkan hanya mengidentifikasi kewenangan presiden sebagai kepala negara antara lain membuat perjanjian internasional. Oleh karena itu, pasal ini sulit digunakan sebagai dasar yang kuat untuk mengetahui posisi perjanjian internasional dalam sistem hukum Indonesia. Demikian halnya, para ahli juga mengalami kesulitan untuk menemukan latar belakang dirumuskannya pasal yang singkat tersebut.(Agusman dan Sinta, 2008: 170)

Lebih lanjut, ketika Indonesia berbentuk Republik Indonesia Serikat, pembuatan perjanjian internasional didasarkan pada Pasal 175 Konstitusi Republik Indonesia Serikat (RIS) yang menyatakan bahwa:

“(I) Presiden mengadakan dan mengesahkan segala perjanjian (traktat) dan persetujuan lain dengan negaranegara lain kecuali ditentukan lain dengan undang-undang federal, perjanjian atau persetujuan lain tidak disahkan, melainkan sesudah disetujui dengan undang-undang (2) Masuk dalam dan memutuskan perjanjian dan persetujuan lain dilakukan oleh Presiden dengan kuasa undang-undang"

Adapun dalam kurun waktu Undang-Undang Dasar Semestara (UUDS) 1950, pengaturan tentang perjanjian internasional tidak jauh berbeda dengan Pasal 175 Konstitusi RIS. Dalam UUDS 1950, perjanjian internasional diatur dalam Pasal 120 yang berbunyi sebagai berikut:

“(I) Presiden mengadakan dan mengesahkan perjanjian (traktat) dan persetujuan lain dengan negaranegara lain. Kecuali ditentukan lain dengan undang-undang perjanjian atau persetujuan lain tidak disahkan, melainkan sesudah disetujui dengan undang-undang (2) Masuk dalam dan memutuskan perjanjian dan persetujuan lain, dilakukan oleh Presiden dengan kuasa undang-undang"

Setelah amandemen ketiga dan keempat UUD 1945, Pasal 11 mengalami perubahan, sehingga decara utuh berbunyi sebagai berikut:

1) Presiden dengan persetujuan DPR menyatakan perang, membuat perjanjian perdamaian dan perjanjian dengan negara lain.

2) Presiden dalam membuat perjanjian internasional lainnya yang menimbulkan akibat yang luas dan mendasar bagi kehidupan rakyat yang terkait dengan beban keuangan negara dan/atau mengharuskan perubahan atau pembentukan undang-undang harus dengan persetujuan Dewan Perwakilan Rakyat.

3) Ketentuan lebih lanjut tentang perjanjian internasional diatur dengan undang-undang”

Amandemen ini tidak menyelesaikan permasalahan politik hukum yang lahir akibat keterbatasan pengaturan pasal 11 UUD 1945. Sedikitnya ada dua hal yang memberikan multitafsir dari bunyi utuh perubahan pasal 11 UUD 1945 ini, yaitu: apakah maksud frasa "perjanjian internasional yang lainnya" dan apa bentuk "persetujuan Dewan Perwakilan Rakyat" dalam ayat (2). Apakah "perjanjian internasional yang lainnya" menekankan pada kriteria perjanjian internasional yang perlu mendapatkan persetujuan DPR atau pada subyek perjanjian internasional lainnya selain negara, yaitu organisasi internasional.

Menurut hemat penulis, ayat (2) harus diartikan tidak terpisah dengan pasal sebelumnya yang menekankan pada perjanjian internasional yang dilakukan Indonesia dengan negara lain. Sehingga, 


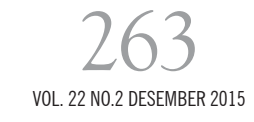

yang dimaksud "perjanjian internasional yang lainnya" adalah perjanjian internasional yang dilakukan Indonesia, selain dengan subyek "negara lain”. Artinya perjanjian internasional yang dilakukan oleh subyek hukum internasional lainnya, yaitu organisasi internasional. Frasa "yang menimbulkan akibat yang luas dan mendasar bagi kehidupan rakyat yang terkait dengan beban keuangan negara dan/atau mengharuskan perubahan atau pembentukan undang-undang" adalah kriteria bagi perjanjian internasional yang dilakukan oleh Indonesia dengan organisasi internasional yang harus mendapatkan persetujuan DPR. Adapun perjanjian internasional yang dilakukan oleh Indonesia dengan negara lain sudah jelas disebutkan dalam ayat (1) harus mendapatkan persetujuan DPR. Seperti yang dikemukakan oleh Prof. Utrecht, UU semacam ini adalah UU dalam arti formil (Wet in formele zin). Hal ini tercermin dari penjelasan Utrecht tentang mekanisme Pasal 11 UUD 1945: yaitu suatu perjanjian internasional harus terlebih dahulu mendapat persetujuan DPR dan dituangkan dalam suatu undang-undang persetujuan (goedkeuringswet) yang bersifat undang-undang formil saja. Kemudian, setelah mendapat persetujuan DPR, Presiden melakukan pengesahan yang disebut dengan "ratifikasi” (Idris, 2013:262). Melalui penjelasan ini, Utrecht hendak menegaskan bahwa UU ratifikasi (goedkeuringswet) ini adalah bukan UU yang memuat perjanjian internasional dari segi materiil. Berbeda dengan Utrecht, dalam pengujian UU Nomor 38 Tahun 2008, nampaknya $\mathrm{MK}$ ingin menegaskan bahwa UU ratifikasi adalah bagian yang tidak terpisahkan dengan perjanjian internasional itu sendiri. MK tidak memberikan kriteria formil ataupun materiil dan bilamana dapat diuji oleh MK. Dalam hal ini, MK menegaskan bahwa UU yang meratifikasi Piagam ASEAN tidak berbeda dengan UU lainnya dan tidak menemukan alasan yang meyakinkan mengapa UU ini harus dibedakan dengan UU lainnya, sekalipun tersedia doktrin atau referensi yang menyatakan sebaliknya. Melalui pengujian UU Nomor 38 Tahun 2008 tersebut, MK menegaskan bahwa selama perjanjian internasional dibuat dalam bentuk UU maka semua perjanjian internasional dapat diuji oleh MK. Artinya, semua perjanjian internasional lainnya dapat diuji dan berpotensi untuk dinyatakan bertentangan dengan UUD.

\section{Politik Hukum Perjanjian Internasional Indonesia Dalam Undang-Undang Nomor 24 Tahun 2000 tentang Perjanjian Indonesia}

Sebelum lahirnya Undang-Undang Nomor 24 Tahun 2000, pedoman yang digunakan untuk membuat dan mengesahkan perjanjian internasional di Indonesia adalah Surat Presiden No. 2826/ HK/1960 tanggal 22 Agustus 1960, yang mengatur mengenai pengesahan melalui undang-undang atau Keputusan Presiden.

Surat tersebut terkait dengan praktek pembuatan perjanjian internasional di Indonesia hanya didasarkan atas pertimbangan kecepatan dan kemudahan saja tanpa mempertimbangkan aspek yuridis lainnya yang lebih penting, sehingga hal ini mengarah pada praktek fiat accompli yuridis terhadap kekuasaan DPR dalam hal pembuatan perjanjian internasional (Dewanto, 2009:328). Berbeda dengan Haryono, Bagir Manan memberikan kesimpulan bahwa Surat Presiden No. 2826/ HK/1960 jika ditinjau dari sudut pandang hukum tatanegara dapat digolongkan sebagai konvensi 


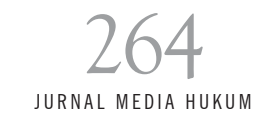

ketatanegaraan yang tertulis sehingga sepanjanng belum ada peraturan perundang-undangan yang mengatur mengenai tata cara pembuatan/memasuki perjanjian atau persetujuan internasional maka surat tersebut berlaku sebagai hukum yang harus dipatuhi (Dewanto,2009:328).

Pada tanggal 23 Oktober 2000. Pemerintah Indonesia mengundangkan Undang-undang Nomor 24 Tahun 2000 tentang Perjanjian Internasional (selanjutnya disingkat UUPI). Pasal 9 UUPI mengatur sebagai berikut:

1) Pengesahan perjanjian internasional oleh Pemerintah Republik Indonesia dilakukan sepanjang dipersyaratkan oleh perjanjian internasional tersebut.

2) Pengesahan perjanjian internasional sebagaimana dimaksud dalam ayat (1) dilakukan dengan undangundang atau keputusan presiden

Berdasarkan Pasal 9 ayat (2) UUPI tersebut diatas, dalam prakteknya ada dua macam pengesahan perjanjian internasional di Indonesia, yaitu dengan undang-undang dan keputusan presiden. Dalam menentukan ratifikasi perjanjian internasional apakah akan diratifikasi dengan Undang- undang atau dengan keppres, dilihat dari substansi atau materi perjanjian bukan berdasarkan bentuk dan nama (nomenclature) perjanjian, dan dilakukan oleh Departement Luar Negeri. Klasifikasi menurut materi perjanjian dimaksud agar terciptanya kepastian hukum dan keseragaman atas bentuk pengesahan perjanjian internasional dengan undang-undang. Dalam Pasal 10 UUPI ditentukan pengesahan perjanjian internasional dilakukan dengan undang- undang apabila berkenaan dengan bidang-bidang tersebut dibawah ini:

a. Masalah politik, perdamaian, dan keamanan negara;

b. Perubahan wilayah dan penetapan batas wilayah Negara Republik Indonesia;

c. Kedaulatan atau hak berdaulat Negara;

d. Hak asasi manusia dan lin gkungan hidup;

e. Pembentukan kaidah hukum baru;

f. Pinjaman dan atau hibah luar negeri.

Selanjutnya pengesahan perjanjian internasional yang materinya tidak termasuk dalam pasal 10 UUPI diatur dalam pasal 11 ayat (1) yang berbunyi "Pengesahan perjanjian internasional yang materinya tidak termasuk materi sebagaimanadimaksud Pasal 10, dilakukan keputusan presiden".

Ketidakjelasan politik hukum perjanjian internasional dalam UUD 1945, seharusnya dapat diselesaikan dengan diundangkannya UU No. 24 tahun 2000 tentang Perjanjian Internasional sebagaimana amanat Pasal 11 Ayat (3) UUD 1945. Sebaliknya, UUPI ini memunculkan "kerumitan" baru dalam politik hukum perjanjian internasional. Dalam UU tersebut kata-kata "persetujuan DPR” yang dimuat dalam Pasal 11 ayat (1) dan (2), tidak tercantum dalam UUPI, undang-undang ini menggunakan kata "pengesahan”. Pada Pasal 1 butir 2 UUPI, pengesahan diartikan sebagai "perbuatan hukum untuk mengikatkan diri pada suatu perjanjian internasional dalam bentuk ratifikasi, aksesi, penerimaan dan penyetujuan". Arti kata pengesahaan tersebut sebenarnya merupakan adopsi 


\section{5 \\ VOL. 22 N0.2 DESEMBER 2015}

dari Konvensi Wina 1969 tentang Perjanjian Internasional, Pasal 2 ayat 1 (b) yaitu:

"Ratification, acceptance, approval and accession mean in each case the international act so named whereby a State establishes on international plane its consent to be bound."

Apabila mengacu pada Pasal 24 Konvensi Wina 1969, suatu perjanjian internasional berlaku bagi negara apabila telah menyatakan terikat (consent to be bound) dengan cara-cara yang ditentukan oleh suatu perjanjian internasional (bisa ratifikasi, penerimaan, penyetujuan, aksesi). Konvensi Wina 1969 tidak mengatur bagaimana prosedur hukum internal suatu negara mengakui suatu perjanjian internasional. Pasal 11 UUD 1945 jo Pasal 9 UU No. 24 tahun 2000 merupakan prosedur hukum internal Indonesia (politik hukum) yang mengatur bagaimana Indonesia terikat atas perjanjian internasional. Jika ditafsirkan secara sistematis, pengesahan dalam Pasal 9 ayat 2 UU No. 24 tahun 2000 merupakan turunan dari kata "persetujuan DPR" dalm Pasal 11 UUD 1945. Dengan demikian, pengesahan dalam Pasal 9 ayat 2 UU No. 24 tahun 2000 harus dilakukan sebelum adanya pengesahan eksternal yang terdapat dalam Pasal 9 ayat 1.

Dalam hal ini penulis setuju dengan pendapat Damos D. Agusman, bahwa UU/Keppres pengesahan perjanjian internasional hanyalah “jubah” persetujuan DPR, sehingga hanya bersifat formal dan penetapan.

\section{Politik Hukum Perjanjian Internasional Indonesia Dalam Undang-Undang Nomor 12} Tahun 2011 tentang Pembentukan Peraturan Perundang-Undangan

Peraturan yang mengatur tentang hierarkhi perundang-undangan di Indonesia sudah mengalami beberapa kali perubahan, mulai dari TAP MPRS Nomor 20/MPRS/1966, TAP MPR Nomor III/MPR/2000, Undang-Undang Nomor 10 Tahun 2004 tantang Pembentukan Peraturan Perundang-Undangan sampai dengan perubahan yang terbaru dalam Undang-Undang Nomor 12 Tahun 2011 tentang Pembentukan Peraturan Perundang-Undangan sebagai pengganti UndangUndang Nomor 10 Tahun 2004 tantang Pembentukan Peraturan Perundang-Undangan. Dari beberapa pengaturan tersebut, tidak satupun yang menempatkan perjanjian internasional sebagai peraturan yang mengikat Indonesia dalam hierarkhi peraturan perundang-undangan. Dan kekuatan hukumnya ditegaskan pada pasal 7 ayat 2: "Kekuatan hukum Peraturan Perundang-undangan sesuai dengan hierarki sebagaimana dimaksud pada ayat (1)".

Hans Kelsen sebagai penganut aliran monisme menyebutkan bahwa tidak menutup kemungkinan hukum internasional mendapat tempat secara otomatis dalam hierarki peraturan perundang-undangan suatu negara. Hal tersebut dimungkinkan oleh Hans Kelsen dengan menempatkan statute dalam hierarkinya. Demikian halnya Hamid Attamimi dalam menjabarkan teori Nawiasky juga mengemukakan bahwa Staatsgrundgesetz adalah berupa Batang Tubuh UUD 1945, Tap MPR, dan Konvensi Ketatanegaraan. Artinya suatu konvensi pun dapat menjadi aturan dasar negara (staatsgrundgesetz) yang setara dengan Batang Tubuh UUD 1945 dan Tap MPR. Indrati 


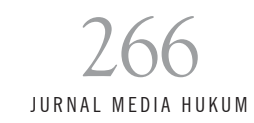

dalam bukunya menyebutkan bahwa yang dimaksud konvensi ketatanegaraan adalah hukum dasar tidak tertulis yang tumbuh dan terpelihara di dalam masyarakat.

\section{B. Pengaruh Politik Hukum Perjanjian Internasional Terhadap Kepentingan Nasional Indonesia}

1. Pengaruh Politik Hukum Perjanjian Internasional Terhadap Kepentingan Nasional Indonesia di Era Globalisasi

Menurut Damos D. Agusman, terdapat dua perkembangan pesat dewasa ini telah membuat sistem Indonesia menggeliat. Pertama adalah perkembangan internal yaitu reformasi ketatanegaraan Indonesia yang ditandai dengan proses demokratisasi dalam bidang hukum untuk menuju suatu sistem hukum modern, dan kedua adalah faktor eksternal yaitu globalisasi yang memaksa kehadiran instrumen asing seperti perjanjian internasional di dalam sistem hukum yang sedang bereformasi (Agusman, 2008:257). Ditengah-tengah perkembangan masyarakat global tersebut, ketidakjelasan politik hukum perjanjian internasional Indonesia, memberikan pengaruh terhadap beberapa hal, diantaranya adalah:

a. Terhambatnya Pelaksanaan Politik Luar Negeri Indonesia

Ketidakjelasan UUD 1945 dalam mengatur masalah perjanjian internasional dalam sistem hukum Indonesia berpotensi mengganggu pelaksanaan politik luar negeri untuk kepentingan nasional. Potensi tersebut muncul karena pelaksanaan politik internasional melalui ratifikasi dan penerapan perjanjian internasional menjadi terhambat. Masing-masing negara temasuk Indonesia memiliki pertimbangannya sendiri dalam menganut suatu aliran, apakah monisme ataukah dualisme. Politik luar negeri mau tidak mau berkenaan dengan pertimbanganpertimbangan baik kekurangan maupun kelebihan masing-masing aliran.

b. Ketidakpastian Posisi dan Penerapan Perjanjian Internasional Yang Telah Diikuti Indonesia dalam Sistem Hukum Indonesia

Dari perspektif nasional Indonesia, perjanjian internasional mendapatkan kekuatan mengikat berdasarkan Pasal 11 Undang-Undang Dasar Negara Republik Indonesia Tahun 1945. Namun, keterbatasan pengaturan mengenai perjanjian intenasional dalam Undang-Undang Dasar Negara Republik Indonesia Tahun 1945 mengakibatkan ketidakpastian dalam menerapkan hukum internasional, khususnya perjanjian internasional ke dalam ranah hukum nasional Indonesia. Ketidakjelasan politik hukum perjanjian internasional yang dianut oleh Indonesia, dapat menyebabkan perjanjian internasional rawan tidak dapat diterapkan dalam sistem hukum Indonesia karena undang-undang pelaksanaannya digugat di Mahkamah Konstitusi.

c. Terancamnya Pelaksanaan Kepentingan Nasional Indonesia Dalam Hubungan Internasional Ketidakpastian posisi dan penerapan perjanjian internasional yang diikuti oleh Indonesia, dapat mengancam pelaksanaan kepentingan nasional Indonesia dalam hubungan internasional. Dalam Putusan MK atas permohonan judicial review UU Nomor 38 Tahun 2008, MK mengeluarkan dalil sebagai berikut:

"sekalipun Indonesia telah terikat dalam suatu perjanjian ineternasional, namun sebagai sebuah negara 


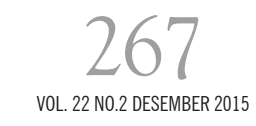

yang berdaulat Negara Indonesia tetap mempunyai hak secara mandiri (unilateral) untuk menerik diri dari perjanjian itu"

Selanjutnya MK menyatakan:

bahwa hal ini dimungkinkan dengan ketentuan Pasal 18 huruf h Undang-Undang Nomor 24 Tahun 2000 tentang Perjanjian Internasional yang menyatakan: "Perjanjian internasional berakhir apabila:...... h. Terdapat hal-hal yang merugikan kepentingan nasional”.

Indonesia tidak mungkin membatalkan sepihak perjanjian perbatasan dengan negara tetangga dengan dalih kepentingan nasional, karena ini dilarang oleh Konvensi Wina 1969 tentang Perjanjian Internasional. Sebaliknya, Indonesia tidak mengharapkan negara-negara tetangga membatalkan perjanjian perbatasan yang telah ada selama ini karena akan berpotensi konflik antar negara. Menurut Pasal 62 (2) Konvensi Wina 1969 tentang Perjanjian Internasional, "perubahan fundamental" pun tidak dapat dijadikan alasan untuk mengakhiri perjanjian perbatasan.(Agusman, 2008:267)

2. Kekuatan Mengikat Perjanjian Internasional yang Diikuti dan atau Ditandatangani oleh Indonesia

Dengan hadirnya perjanjian internasional sebagai instrumen asing dalam sistem hukum nasional, membuka kemungkinan terjadinya benturan antara sistem hukum nasional dengan perjanjian internasional.

Dalam amar putusannya, MK Menyatakan menolak permohonan para Pemohon untuk seluruhnya. Artinya, Piagam ASEAN tidak bertentangan dengan UUD.

Dalam Putusan Mahkamah Konstitusi Nomor 33/PUU-IX/2011 Mengenai Pengujian Undang Undang Nomor 38 Tahun 2008 tentang Pengesahan Piagam ASEAN, MK menyatakan bahwa:

'Sekalipun Indonesia telah terikat dalam suatu perjanjian internasional, namun sebagai sebuah negara yang berdaulat Negara Indonesia tetap mempunyai hak secara mandiri (unilateral) untuk menarik diri dari perjanjian itu.' Selanjutnya MK mengatakan bahwa hal ini dimungkinkan dengan ketentuan Pasal I 8 huruf h Undang-Undang Nomor 24 Tahun 2000 tentang Perjanjian Internasional yang menyatakan, "Perjanjian internasional berakhir apabila:... h. terdapat hal-hal yang merugikan kepentingan nasional”.

Konvensi Wina 1969 tentang perjanjian internasional telah mengatur secara ketat bagaimana suatu Negara dapat menarik diri dari suatu perjanjian dan tidak lagi membuka ruang bagi tindakan unilateral penarikan diri sepanjang tindakan itu disetujui oleh para pihak perjanjian. Selain itu, Konvensi ini melarang Negara mengingkari perjanjian dengan menggunakan tameng hukum nasionalnya. Prinsip seperti yang dimaksud MK ini jelas tidak bisa lagi diterapkan. Indonesia tidak mungkin membatalkan sepihak perjanjian perbatasannya dengan Negara tetangga dengan dalih kepentingan nasional. Sebaliknya, Indonesia tidak mengharapkan Negara tetangga membatalkan perjanjian batas yang telah ada selama ini karena akan berpotensi pada konflik antar Negara. Bahkan, menurut Konvensi Wina, 'perubahan fundamental' pun tidak dapat dijadikan alasan untuk mengakhiri perjanjian perbatasan. 


\section{8}

JURNAL MEDIA HUKUM

Dalil MK ini akan membuka boks pandora tentang perjanjian-perjanjian perbatasan yang telah diratifikasi oleh Indonesia melalui UU karena secara konstitutional dapat dianulir oleh MK dan akan melahirkan wanprestasi di ranah hukum internasional. Situasi ini akan menggiring Indonesia ke dilema hukum, yaitu pentaatan terhadap hukum nasional akan melahirkan pelanggaran terhadap hukum internasional dan sebaliknya pentaatan terhadap perjanjian mengakibatkan pelanggaran konstitusi.(Agusman, 2008:267)

\section{Konsep Politik Hukum Perjanjian Internasional Dalam Rangka Mewujudkan Tertib Hukum di Indonesia Kedepan}

Praktik Indonesia terkait relasi hukum nasional dengan hukum internasional mencerminkan adanya penerimaan baik terhadap ajaran madzhab monisme maupun dualisme. Namun pada saat yang sama juga bisa dikatakan bahwa Indonesia tengah mempraktekkan pendekatan yang lebih prakmatis, yaitu pendekatan yang lebih fleksibel yang menitikberatkan pada pokok persoalannya (subject matter), sampai sejauhmana ia memiliki dampak terhadap hukum nasional (Latifulhayat, 2011:186). Selama ini, perdebatan pemilihan aliran berkutat pada dua kubu aliran inkorporasi dan transformasi yang hingga saat ini tidak ada ujungnya. Menurut penulis, perlunya dimunculkan dan dikaji aliran lainnya yang tepat bagi pemilihan pendekatan atau teori tentang mekanisme adopsi (penerimaan) perjanjian internasional dalam sistem hukum nasional Indonesia. Aliran yang dimaksudkan oleh penulis adalah aliran prakmatis.

Mazhab harmonisasi diperkenalkan dan dipopulerkan oleh Dionisio Anzilloti dan Fitzmaurice yang dimaksudkan sebagai konsep alternatif untuk menengahi perdebatan teoritis antara madzhab monisme dan dualisme. Dalam salah satu kuliahnya yang disampaikan di The Hague Academy of International Law pada tahun 1957, Fitzmaurice mengatakan sebagai berikut: (Latifulhayat, 2011:181)

the entire monist-dualist controversy is unreal, artficial, and strictly beside the point, because it assumes something that has to exist for there to be any controversy at all - and which in fact does not exist namely a commonfield in which the two legal orders under discussion both simultanneously have their spheres of activity.

Paham ini menolak superioritas diantara hukum internasional dan hukum nasional. Madzhab harmonisasi ini diakui oleh banyak pakar lebih merupakan sebuah pendekatan pragmatis-teoritis. Memperhatikan esensinya, Madzhab ini mirip dengan madzhab dualisme. Perbedaannya terletak pada bentuk pendekatannya Madzhab Harmonisasi lebih menekankan kepada koordinasi (theory of coordination), karena madzhab ini berpendapat tidak ada konflik antara sistem hukum nasional dan hukum internasional. Sedangkan Madzhab Dualisme cenderung pada pendekatan konfrontasi, karena madzhab dualisme mengklaim bahwa hukum internasional dan hukum nasional merupakan dua sistem hukum yang berbeda (teory of confrontation) (Latifulhayat, 2011:182).

Dalam praktiknya negara-negara tidak sepenuhnya konsisten melaksanakan doktrin inkorporasi 


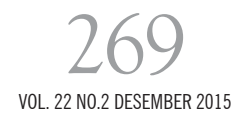

atau transformasi. Di Inggris menerapkan doktrin inkorporasi hanya untuk hukum kebiasaan internasional, sedangkan untuk perjanjian diberlakukan doktrin transformasi. Praktik di Belanda sebaliknya, hukum kebiasaan internasional tidak secara otomatis merupakan bagian dari hukum nasional. Di Belgia hukum kebiasaan internasional tidak bisa diterapkan di pengadilan nasional kecuali apabila secara formal telah ditransformasikan kedalam perundang-undangan Belgia. Sementara di Swiss, hanya hukum kebiasaan internasional yang mengandung norma jus cogen yang secara otomatis menjadi bagian dari hukum nasional.(Latifulhayat, 2011:186)

Apabila Indonesia akan menerapkan pemberlakuan hukum internasional secara pragmatis, maka dalam prakteknya Indonesia akan membuat 3 (tiga) grade perjanjian internasional, yaitu (Aminato dan Merdekawati, 2015:87).

a. Perjanjian internasional yang akan dapat langsung berlaku tanpa mensyaratkan adanya proses ratifikasi/aksesi. Terhadap perjanjian dalam kategori ini maka pilihan Indonesia adalah menerapkan teori Inkorporasi (automatic standing incorporation)

b. Perjanjian yang memerlukan transformasi dalam hukum nasional (legislative ad hoc incorporation) dan memerlukan persetujuan Dewan Perwakilan Rakyat dalamproses transformasinya, Wujud transformasinya adalah Undang-Undang Ratifikasi.

c. Perjanjian internasional yang memerlukan transformasi dalam hukum nasional (legislative ad hoc incorporation) namun tidak membutuhkan persetujuan Dewan Perwakilan Rakyat dalam proses transformasinya. Wujud transformasinya adalah Peraturan Presiden.

Setelah hukum internasional diterima sebagai bagian dari hukum nasional, pertanyaan selanjutnya adalah penyangkut posisi atau hierarkhi hukum internasional dalam tertib hukum nasional. Secara garis besar ada dua praktik negara-negara berkaitan dengan hal ini. Pertama, negara yang menempatkan ketentuan hukum internasional dalam posisi yang sama dengan perundangundangan nasional lainnya (the same footing as national legislation of domestic origin). Konsekuensinya, perundang-undangan nasional dapat mengamandemen atau bahkan membatalkan ketentuan hukum internasional tersebut. Kedua, negara yang cenderung menempatkan ketentuan hukum internasional lebih tinggi dari perundang-undangan nasional. Menurut Cassese, kecenderungan ini umumnya dipraktikkan di negara-negara yang memiliki konstitusi relatif kaku (rigid), yaitu konstitusi yang menetapkan persuaratan khusus untuk melakukan perubahan (amandemen) terhadapnya. Dalam konstitusi seperti ini, apabila terdapat ketentuan yang mengatur mengenai transformasi hukum internasional kedalam hukum nasional, maka eksistensi hukum internasional akan memiliki kekuatan konstitusional yang memadai dan oleh karenanya akan menempati kedudukan yang lebih tinggi dibanding perundang-undangan nasional lainnya (Latifulhayat, 2011:187).

Untuk mereposisi konsep politik hukum perjanjian internasional dalam rangka mewujudkan tertib hukum di Indonesia kedepan, dilakukan dengan melakukan pembaharuan hukum sebagai berikut:

\section{Amandemen Pasal 11 UUD 1945}




\section{0}

JURNAL MEDIA HUKUM

Pasal 11 UUD 1945 memuat pengaturan mengenai hukum internasional bersama-sama dengan kekuasaan presiden untuk menyatakan perang dan membuat perdamaian. Pengaturan tentang perjanjian internasional yang begitu singkat mengakibatkan keridakpastian hukum. Pasal 11 UUD 1945 berada di bawah bab mengenai Kekuasaan Pemerintah Negara, oleh karena itu Pasal 11 UUD 1945, dalam hal perjanjian internasional, hanya mengatur mengenai kewenangan presiden untuk membuat perjanjian internasional saja. Mekanisme pembuatan perjanjian internasional dan kedudukan perjanjian internasional dalam sistem hukum nasional Indonesia belum diatur dalam Pasal 11 UUD 1945.

Perubahan Pasal 11UUD 1945 dari masa ke masa selama ini tidak membahas pengaturan mengenai mekanisme pembuatan perjanjian internasional maupun kedudukan perjanjian internasional. Pasal 11 UUD 1945 sempat mengalami perubahan pada amandemen ke-3 di Sidang Tahunan MPR, 10 November 2001 yaitu mengalami penambahan ayat (2) dan ayat (3). Indonesia memberikan porsi pengaturan mengenai perjanjian internasional sangat sedikit dalam konstitusinya apabila dibandingkan dengan Konstitusi milik Belanda, Amerika Serikat dan Afrika Selatan (http:/ /pustaka.unpad.ac.id/wp-content/uploads/2015/03/Status-Perjanjian-Internasional-dalam-SistemHukum-Indonesia.pdf.)

Permasalahan yang sebenarnya terjadi adalah terletak pada ketentuan konstitusi Indonesia terkait dengan relasi antara hukum nasional dan hukum internasional. Sehubungan dengan perjanjian internasional, para pakar hukum internasional berpendapat bahwa "kearifan internasional" (international wisdom) mengenai perjanjian internasional tidak begitu rumit: "when a state enters an agreement that evinces an intention to be governed by international law, it puts itself under an international law obligation to comply with agreement". Jadi yang menjadi persoalan pokoknya adalah keragaman pada "kearifan domestik" (domestic wisdom) di masing-masing negara. Dengan perkataan lain, ini menyangkut wilayah masing-masing negara.

Indonesia sebaiknya menggunakan pendekatan yang lebih prakmatis, yaitu pendekatan yang lebih fleksibel sesuai dengan kasus dan situasi yang dihadapi. Pertimbangan utamanya adalah bagaimana caranya agar ketentuan hukum internasional dapat dilaksanakan. Pendekatan ini tidak mempersoalkan apakah norma hukum internasional itu berasal dari hukum kebiasaan atau perjanjian internasional, tapi lebih menitikberatkan kepada pokok persoalannya, sejauhmana memiliki dampak pada kepentingan nasional.

\section{Revisi Undang-Undang Nomor 24 Tahun 2000 tentang Perjanjian Indonesia}

Pasal 9 Undang-Undang Nomor 24 Tahun 2000 Tentang Perjanjian Internasional juga dapat dikatakan tidak secara tuntas dan jelas membahas substansi prosedur internal ratifikasi perjanjian internasional. Hal tersebut ditunjukan dengan adanya beberapa penafsiran. Penafsiran pertama, menganggap undang-undang atau keputusan presiden (saat ini peraturan presiden) yang mengesahkan suatu perjanjian internasional mentransformasikan perjanjian internasional tersebut menjadi hukum nasional. Penafsiran kedua memandang undang-undang atau peraturan presiden 


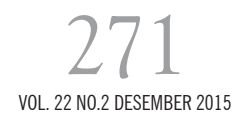

merupakan persetujuan DPR atau Presiden yang menginkorporasi perjanjian internasional ke dalam hukum nasional. Perjanjian Internasional berlaku di Indonesia pada bentuknya yang asli sebagai norma hukum internasional. Penafsiran yang terakhir adalah memandang undang-undang atau penetapan presiden sebagai bentuk persetujuan DPR atau Presiden untuk mengikatkan diri pada perjanjian internasional dalam tatanan internasional. Dengan demikian Indonesia membutuhkan produk legislasi lain tersendiri untuk mengonversi materi yang diatur perjanjian internasional ke dalam hukum nasional.

Pengesahan yang dipahami dalam ilmu perundang-undangan sangat berbeda dengan prosedur eksternal ratifikasi. Pengesahan DPR dalam bentuk Undang-Undang pengesahan perjanjian internasional bukan merupakan pengikatan diri pada perjanjian internasional yang dimaksud dalam Article 2 (1) $b$ Vienna Convention on The Law of Treaties 1969. Dengan adanya beragam penafsiran tersebut, terutama penafsiran ketiga, bahwa Undang-Undang No. 24 Tahun 2000 tentang Perjanjian Internasional belum memisahkan secara tegas prosedur internal dengan prosedur external ratifikasi perjanjian internasional di Indonesia. Kedepan, revisi terhadap UUPI harus menegaskan tentang prosedur internal dan memisahkannya dengan prosedur external ratifikasi perjanjian internasional di Indonesia.

\section{Revisi Undang-Undang Nomor 12 Tahun 2011 tentang Pembentukan Peraturan Perundang- Undangan}

Revisi Undang-Undang Nomor 12 Tahun 2011 tentang Pembentukan Peraturan Perundangundangan kedepan diharapkan menempatkan perjanjian internasional yang telah mengikat Indonesia kedalam hierarkhi peraturan perundang-undangan Nasional. Sebelumnya, masalah penempatan perjanjian nasional sebagai sumber hukum nasional Indonesia yang belum diatur dalam Pasal 11 maupun pasal lain dalam UUD 1945 dapat terselesaikan. Pencantuman perjanjian internasional dalam bentuk mandiri dalam hierarkhi Peraturan Perundang-undangan di Indonesia tentu akan memberikan perubahan yang masif dalam pengaturan tentang perjanjian internasional yang diatur dalam UU No. 24 Tahun 2000 tentang Perjanjian Internasional, khususnya terkait dengan persoalan bentuk dan mekanisme ratifikasi.

Menilik konsekuensi dalam sebuah hierarkhi akan berlaku hub sub ordinasi, maka jika Indonesia akan mengikuti model pencantuman perjanjian internasional dalam hierarkhi pembentukan undang-undang (apakah semua kualifikasi perjanjian internasional atau hanya perjanjian internasional dalam kualifikasi tertentu) dan dalam level mana pencantumannya harus mendapat perhatian yang serius dan untuk menjamin konsistensinya harus ditetapkan dalam satu norma hukum. Sebagaimana telah diuraikan bahwa saat ini perjanjian internasional di Indonesia dapat dikualifikasikan dalam 3 (tiga) kategori sebagai berikut:

a. Perjanjian Internasional yang akan dapat langsung berlaku tanpa mempersyaratkan adanya proses ratifikasi/aksesi.

b. Perjanjian internasional yang memerlukan transformasi dalam hukum nasional (legislative ad 
hoc incorporation) dan memerlukan persetujuan Dewan Perwakilan Rakyat dalam proses transformasinya.

c. Perjanjian internasional yang memerlukan transformasi dalam hukum nasional (legislative ad hoc incorporation) namun tidak membutuhkan persetujuan Dewan Perwakilan Rakyat dalam proses transformasinya.

Masing-masing kategori ini belum ada kualifikasi yang spesifik sehingga praktek inkorporasi dalam pengkategotian tersebut masih terjadi. Hal ini jika tidak diatasi dengan baik justru berpotensi besar menimbulkan kekacauan hukum ketika perjanjian internasional dimasukkan dalam sistem hierarkhi pembentukan undang-undang di Indonesia. Apabila arah politik hukum dalam revisi Undang-Undang No. 24 Tahun 2000 tentang Perjanjian InternasionaL dan Undang-Undang Nomor 12 Tahun 2011 tentang Pembentukan Peraturan Perundang-undangan dilakukan dengan baik dalam mengatur 3 (tiga) kategori diatas, maka ketentuan dalam Pasal 11 UUD 1945 tidak perlu mengalami perubahan karena dari awal konstitusi tidak pernah mengharuskan suatu perjanjian internasional yang sudah diratifikasi/diaksesi oleh Pemerintah Indonesia harus diwadahi dalam baju undang-undang atau peraturan presiden.

\section{PENUTUP}

Ketidakjelasan politik hukum perjanjian internasional Indonesia akan memberikan pengaruh terhadap kepentingan nasional Indonesia di era globalisasi, yaitu: a) terhambatnya pelaksanaan politik luar negeri Indonesia; b) ketidakpastian posisi dan penerapan perjanjian internasional yang telah diikuti Indonesia dalam sistem hukum Indonesia; 3) terancamnya pelaksanaan kepentingan nasional Indonesia dalam hubungan internasional. Untuk mereposisi konsep politik hukum perjanjian internasional dalam rangka mewujudkan tertib hukum di Indonesia kedepan, perlu dilakukan beberapa hal berikut ini: 1) amandemen Pasal 11 UUD 1945; 2) revisi UndangUndang Nomor 24 Tahun 2000 tentang Perjanjian Indonesia; 3) revisi Undang-Undang Nomor 12 Tahun 2011 tentang Pembentukan Peraturan Perundang-Undangan. Apabila arah politik hukum dalam revisi Undang-Undang No. 24 Tahun 2000 tentang Perjanjian InternasionaL dan UndangUndang Nomor 12 Tahun 2011 tentang Pembentukan Peraturan Perundang-undangan dilakukan dengan baik, maka ketentuan dalam Pasal 11 UUD 1945 tidak perlu mengalami perubahan karena dari awal konstitusi tidak pernah mengharuskan suatu perjanjian internasional yang sudah diratifikasi/diaksesi oleh Pemerintah Indonesia harus diwadahi dalam baju undang-undang atau peraturan presiden.

\section{DAFTAR PUSTAKA}

Idris (eds), 2013, Peran Hukum Dalam Pembangunana Indonesia: Kenyataan, Harapan dan Tantangan, Remaja Rosdakarya, Bandung.

Sinta Dewi, 2012, Perkembangan Hukum Di Indonesia: Tinjauan Retrospeksi Dan Prospektif, Remaja Rosdakarya, Bandung. 
Susi Dwi Harijanti (eds), 2011, Negara Hukum Yang Berkeadilan, Rosda bekerjasama dengan PSKN HTN FH UNPAD, Bandung.

Aminoto dan Agustina Merdekawati, Prospek Penempatan Perjanjian Internasional yang Mengikat Indonesia Dalam Hierarkhi Peraturan Perundang-undangan Indonesia, Mimbar Hukum, Volume 27, Nomor 1, Februari 2015.

Damos Dumali Agusman, Status Hukum Perjanjian Internasional Dalam Hukum Nasional RI: Dari Perspektif Praktik Di Indonesia, Indonesia Jurnal of International Law, Volume 5 Nomor 3 April 2008.

Muhammad Yamin, Naskah Persiapan Undang-Undang Dasar 1945 (Preparatory Documents to the Constitution of 1945), Vol.1.

Wisnu Ayo Dewanto, Status Hukum Internasional Dalam Sistem Hukum Di Indonesia, Mimbar Hukum, Volume 21, Nomor 2, Juni 2009.

Garry Gumelar Pratama, Status Perjanjian Internasional dalam Sistem Hukum Indonesia Berdasarkan Politik Luar Negeri dan Pasal 11 UUD 1945, http://pustaka.unpad.ac.id/wp-content/uploads/ 2015/03/Status-Perjanjian-Internasional-dalam-Sistem-Hukum-Indonesia.pdf. Diakses tanggal 15 Oktober 2015 pukul 16.00 WIB. 